\title{
Variation in quality of newly hatched chicks from Japanese breeder quail fed guava extract
}

\author{
H.P.F. Xavier', N.S.M. Leandro1, A.G. Mascarenhas' ${ }^{1}$, I.C.S. de Araújo², N.F. de Oliveira1, A.L. \\ Pinheiro ${ }^{1}$, H.F. de Oliveira ${ }^{1 \#}$ \& H.H. de C. Mello ${ }^{1}$ \\ ${ }^{1}$ Federal University of Goiás, Department of Animal Science, Goiânia, Goiás, Brazil. \\ ${ }^{2}$ Federal University of Minas Gerais, School of Veterinary Medicine, Belo Horizonte, Minas Gerais, Brazil.
}

(Received 16 April 2019; Accepted 5 January 2020; First published online 10 April 2020)

\begin{abstract}
Copyright resides with the authors in terms of the Creative Commons Attribution 4.0 South African License.
See: http://creativecommons.org/licenses/by/4.0/za

Condition of use: The user may copy, distribute, transmit and adapt the work, but must recognize the authors and the South African Journal of Animal Science.
\end{abstract}

\begin{abstract}
The aim of this study was to evaluate the effects of guava extract as a dietary supplement for Japanese quail hens on incubation parameters, intestinal development, and the quality of newly hatched chicks. Six hundred and forty-eight eggs were collected from Japanese quail hens fed diets with 0.0, 3.0, 6.0, and $9.0 \mathrm{~g} / \mathrm{kg}$ of guava extract. The study consisted of four treatments, six replicates, and 27 eggs per replicate. The guava extract contained $2 \%$ ellagic acid. The eggs were incubated at $37.5{ }^{\circ} \mathrm{C}$ and $65 \%$ relative air humidity. The hatch window, hatchability, embryo development in unhatched eggs, quality of newly hatched quails, and intestinal histomorphometry of a duodenum segment were evaluated. Differences among the treatments in hatchability and the hatch window were not significant. The guava extract did not affect mortality rate, live pecking, dead pecking, and contaminated and inverted eggs. The number of infertile eggs was lower in the groups that received 3.0 and $9.0 \mathrm{~g} / \mathrm{kg}$ of extract in their diets. Use of up to $3.0 \mathrm{~g} / \mathrm{kg}$ of guava extract in the diet increased the weight of both eggs and newly hatched chicks. The quality score of newly hatched quail was similar across treatments. The inclusion of $3.0 \mathrm{~g} / \mathrm{kg}$ of guava extract in the diet of Japanese quail breeder hens increased the hatchling weight of the chicks and improved the villus to crypt ratio of their duodenum.
\end{abstract}

Keywords: embryology, embryo metabolism, hatchery, incubation, breeder nutrition

"Corresponding author: helder@zootecnista.com.br

\section{Introduction}

Lipids in quail eggs contain about $56 \%$ to $58 \%$ unsaturated fatty acids, while the yolk contains between 0.20 and $0.21 \mathrm{~g} / \mathrm{kg}$ polyunsaturated fatty acids (PUFAs), which comprise $14 \%$ of the total lipids in the yolk (Genchev, 2012). During early development, the embryo uses lipids and other nutrients in the yolk sac for growth. Polyunsaturated fatty acids are susceptible to oxidation owing to the double bonds in the hydrocarbon chain. Additionally, during the early development of the embryo, the oxidative metabolism leads to the production of large quantities of free radicals in many tissues, making them more susceptible to oxidative damage (Selim et al., 2012). Therefore, there is great demand for an antioxidant system during embryonic development.

Diets that are provided to breeder birds have been studied for their effects on the development of their progeny. Surai et al. (2006) verified that increased selenium concentration in the egg yolk and albumen is related to increased selenium concentration in the tissues of newly hatched quails. Such nutrient transfer from the breeder to the progeny could improve the quality of newly hatched quails.

Sperm membranes are also high in PUFAs (Pappas et al., 2008). The existence of an antioxidant system is crucial to supporting the integrity of sperm membranes, as it contributes to the preservation of the fluidity, flexibility, and permeability required for the fertilization process (Rutz et al., 2007).

Guava fruit contains phenolic compounds and has antioxidant activity (Haida et al., 2015). Its antioxidant phenols act on both the initiation and propagation stages of the oxidative process. Therefore, residues of guava fruit processing may constitute an important source of nutrients and antioxidants in animal feeds. Guava fruit contains ellagic acid, which has an antioxidant effect that is effective in inhibiting lipid peroxidation (Priyadarsini et al., 2002). One of the factors that are responsible for the antioxidant effect of 
guava fruit is its ability to neutralize free radicals. Ellagic acid was found to neutralize reactive oxygen species (ROS) such as hydroxyl radicals, peroxyl radicals, nitrogen dioxide radicals, and peroxynitrite at rate constants that are comparable with those of many well-known antioxidants such as vitamin $\mathrm{E}$ and vitamin $\mathrm{C}$.

Because the transfer of nutrients from the yolk to the quail hatchling is possible, and antioxidants are important in improving spermatozoid quality, the use of an antioxidant in breeder diets in an effort to improve quail quality and performance could be an innovation in nutritional management. Therefore, the present study aimed at evaluating the effect of guava extract, included as an antioxidant in the feeds of Japanese breeder quail, on the incubation parameters, quality, quality score, and intestinal development of newly hatched quail.

\section{Materials and Methods}

The experiment was conducted at the Poultry Facilities of the Federal University of Goiás, Goiânia, Goiás, Brazil (latitude 16³5'33.0"S; longitude 49¹6'51.4"W; altitude $730 \mathrm{~m}$ ). All procedures in this study were conducted according to the protocol with registration $n^{\circ}$ 052/15, and were approved by the Ethics Committee for Animal Use of the Federal University of Goiás.

Six hundred and forty-eight eggs from Japanese quail breeder birds were fed diets that contained one of four levels of guava extract: $0.0,0.3,0.6$, and $0.9 \mathrm{~g} / \mathrm{kg}$. The birds were stratified by bodyweight and previous laying percentage and then randomly assigned to treatments. Their eggs were collected and incubated in an entirely randomized design with four treatments, six replicates, and 27 eggs per replicate. The eggs were collected over three days and stored at room temperature in a ventilated area immediately after collection. Twenty-four hours after the last collection, the eggs were weighed, identified, and incubation commenced. Pointy or round eggs and those with dirty or perforated shells were discarded.

The experimental diets were identical, except that the corn starch was replaced with guava extract, with their formulation being based on corn and soybean meal to meet the nutrient demands of laying Japanese quail, following recommendations from Rostagno et al. (2011) (Table 1). Each diet provided 2800 $\mathrm{Kcal} / \mathrm{kg}$ metabolizable energy, $1.88 \mathrm{~g} / \mathrm{kg}$ sodium, $30.99 \mathrm{~g} . \mathrm{kg}$ calcium, $4.06 \mathrm{~g} / \mathrm{kg}$ available phosphorus, 199.4 $\mathrm{g} / \mathrm{kg}$ crude protein, $10.83 \mathrm{~g} / \mathrm{kg}$ digestible lysine, $8.88 \mathrm{~g} / \mathrm{kg}$ digestible methionine + cysteine, $6.62 \mathrm{~g} / \mathrm{kg}$ digestible threonine and $2.27 \mathrm{~g} / \mathrm{kg}$ digestible tryptophan. Feed and water were provided ad libitum during the experimental period.

Table 1 Composition and nutritional values of experimental diets fed to Japanese quail breeder birds with added guava extract

\begin{tabular}{|c|c|c|c|c|}
\hline \multirow{2}{*}{ Ingredients, g/kg } & \multicolumn{4}{|c|}{ Treatments } \\
\hline & T0.0 & T3.0 & T6.0 & T9.0 \\
\hline Corn & 546.81 & 546.81 & 546.81 & 546.81 \\
\hline Soybean meal & 326.21 & 326.21 & 326.21 & 326.21 \\
\hline Guava extract & 0.00 & 3.00 & 6.00 & 9.00 \\
\hline Starch & 9.00 & 6.00 & 3.00 & 0.00 \\
\hline Vegetable oil & 14.70 & 14.70 & 14.70 & 14.70 \\
\hline Limestone & 57.80 & 57.80 & 57.80 & 57.80 \\
\hline DL-Methionine & 3.52 & 3.52 & 3.52 & 3.52 \\
\hline L-Lysine HCL & 1.89 & 1.89 & 1.89 & 1.89 \\
\hline L-Tryptophan & 0.06 & 0.06 & 0.06 & 0.06 \\
\hline Premix $^{1}$ & 40.00 & 40.00 & 40.00 & 40.00 \\
\hline
\end{tabular}

1 Provided per kg; calcium: $189.65 \mathrm{~g}$; sodium: $37.5 \mathrm{~g}$; phosphorus: $75 \mathrm{~g}$; fluorine: $750 \mathrm{mg}$; retinol: $67.5 \mathrm{mg}$; cholecalciferol: $1.75 \mathrm{mg}$; tocopherol: $1.27 \mathrm{mg}$; menadione: $50 \mathrm{mg}$; thiamine: $82.5 \mathrm{mg}$; riboflavin: $212.5 \mathrm{mg}$; pyridoxine: $125 \mathrm{mg}$; cobalamin: $0.50 \mathrm{mg}$; pantothenic acid: $375 \mathrm{mg}$; niacin: $875 \mathrm{mg}$; folic acid: $37.5 \mathrm{mg}$; biotin: $5 \mathrm{mg}$; choline: 4.875 mg; copper: $225 \mathrm{mg}$ (as CuSO4); Iron: $1.125 \mathrm{mg}$ (as FeSO4); manganese: $2.500 \mathrm{mg}$ (as MnSO4); iodine: $22.5 \mathrm{mg}$ (as $\mathrm{Ca}(\mathrm{IO} 3) 2$ ); zinc: $750 \mathrm{mg}$ (as ZnSO4); selenium: $12.5 \mathrm{mg}$ (as Na2SeO3); zinc bacitracin: $550 \mathrm{mg}$; methionine 28.7 gT0.0: basal diet plus $0.0 \mathrm{~g} / \mathrm{kg}$ guava extract, T3.0: basal diet plus $3 \mathrm{~g} / \mathrm{kg}$ guava extract; T6.0: basal diet plus $6 \mathrm{~g} / \mathrm{kg}$ guava extract; T9.0: basal diet plus $9 \mathrm{~g} / \mathrm{kg}$ guava extract

The guava extract contained $2 \%$ ellagic acid. It was developed by the Bioproduct Innovation Sector of the Pharmacy College of the Federal University of Goiás. To obtain the guava extract, residues from the 
industrial processing of guava fruit, consisting mainly of seeds, bark, and pulp remnants, were provided by Indústria Predilecta Alimentos LTDA (located in Matão-SP, Brazil). The residues were dehydrated in a forced air oven at $40{ }^{\circ} \mathrm{C}$ for 72 hours, after which the material was ground in a knife mill, resulting in a powder that was stored in plastic bags at room temperature, and away from the light. The hydroalcoholic extract was obtained by percolating the plant material in the powder, using $50 \%$ alcohol $(\mathrm{v} / \mathrm{v})$ as a solvent. The amounts of $2 \mathrm{~kg}$ of plant material and $10 \mathrm{~L}$ of solvent were added to a percolator containing filter paper and cotton and the material was macerated for 24 hours.

After the percolation started, there was intense dripping until the solvent was depleted. Care was taken to avoid leaving the powder without solvent to prevent it from drying. Afterwards, the liquid obtained from the percolated powder was retrieved in 10 rounds, based on the method adapted from the Formulário de Fitoterápicos da Farmacopeia Brasileira (BRASIL, 2011). After percolation, the liquid extract was concentrated by solvent evaporation using a fan at room temperature until a solid content of $3.7 \%$ was obtained.

Eggs were incubated in a single-stage hatcher. The temperature of the hatcher was kept at $37.5^{\circ} \mathrm{C}$ and the relative air humidity was maintained at $65 \%$. The hatcher had grid trays so that air circulation and humidity were suitable for the incubation of quail eggs. Eggs were distributed in equal numbers on the trays, to nullify the interference of a potential temperature variation inside the hatcher. The total incubation period was 408 hours. At the end of the first 360 hours, the eggs were placed individually in sealed bags along with an identification tag and transferred to birth trays.

The hatch window began with the eclosion of the first quail and, soon after this, monitoring took place every four hours until the end of the hatch window, which lasted 40 hours. To control the hatch rate, 40 hours after the beginning of the hatch window monitoring ended and quail born after this period were not considered in the data analysis.

In the 4th, 5th, and 6th periods of monitoring the hatch window, 208 newly hatched quails were randomly selected for necropsy, totalling 52 birds per treatment. The quail were euthanized by cervical dislocation. Weights were recorded for yolk sac residue and total intestine with pancreas. A segment of the duodenum was collected.

For the preparation of histological slices, segments of $2.0 \mathrm{~cm}$ of the duodenum were collected and fixed in $10 \%$ formaldehyde and buffered for 24 hours. After fixation, they were stored in $70 \%$ ethanol, processed according to the methodology of Luna (1968), and stained with the haematoxylin-eosin method. The images were obtained at 5x magnification, using an optical microscope (Leica DM 4000B, Leica Microsystems $\mathrm{GmbH}$, Wetzlar, Germany) coupled to a microcomputer. The images were analysed with ImageJ software to record the villus height and crypt depth measurements.

Additional data included egg weight, newly hatched quail weight and length, intestine weight, yolk sac residue weight, quail percentage in the egg, percentage of intestine in the quail and of residue in the yolk sac, hatchability, hatch window, quality score, and embryo diagnosis of unhatched eggs. All quail born within the hatch window were weighed, received a quality score, and had their length measured with a scale graduated in $\mathrm{cm}$ and $\mathrm{mm}$.

In embryo diagnosis, the eggs were opened and evaluated in terms of the presence of an embryo. If an embryo was absent, the egg's fertility was evaluated. If an embryo was present, the authors evaluated whether there was high or low humidity loss and the position of the embryo in the egg to account for reversal cases. Thus, the embryos were classified into four categories according to the development phase at which the interruption occurred. Embryos with only a heart and blood system were categorized as phase 1. Embryos that were already visible, but were small, and had their entire yolk sac out of the abdominal cavity, were categorized in phase 2. Embryos with approximately half of their yolk sac out of the abdominal cavity were categorized in phase 3 . Finally, embryos that had absorbed nearly $100 \%$ of their yolk sacs were categorized in phase 4 (Araújo et al., 2015).

The data were evaluated using analysis of variance and Tukey's test. Data that originated from the embryo diagnosis and the score percentage were evaluated using Fisher's exact test. All analyses were performed using R Development software (2016). The statistical model was:

$$
y_{i j}=m+t_{i}+e_{i j}
$$

Where: $y_{i j}=$ an observation from treatment $\mathrm{i}(\mathrm{i}=1,2,3,4)$ and replicate $\mathrm{j}(\mathrm{j}=1,2,3, \ldots, 6)$;

$m=$ the overall mean;

$t_{i}=$ the fixed effect of treatment $\mathrm{i}(\mathrm{i}=1,2,3,4)$; and

$e_{i j}=$ the random error with mean 0 and variance $\sigma^{2}$. Effects were declared significant at $\alpha=0.05$.

\section{Results and Discussion}


No statistical difference was observed among the treatments for the hatchability percentage and for the hatch window (Table 2). The hatch window is presented in Figure 1.

Table 2 Hatchability and hatch window of eggs from Japanese quail breeders fed diets containing different levels of guava extract

\begin{tabular}{lcc}
\hline Treatment & Hatchability, \% & Duration of hatch window $(\mathrm{h})$ \\
\hline 0 g/kg guava extract & $93.30 \pm 3.19$ & 24 \\
3 g/kg guava extract & $94.06 \pm 3.19$ & 28 \\
6 g/kg guava extract & $87.42 \pm 3.19$ & 25 \\
9 g/kg guava extract & $92.68 \pm 3.19$ & 27 \\
\hline$P$-value & 0.472 & 0.939 \\
\hline
\end{tabular}

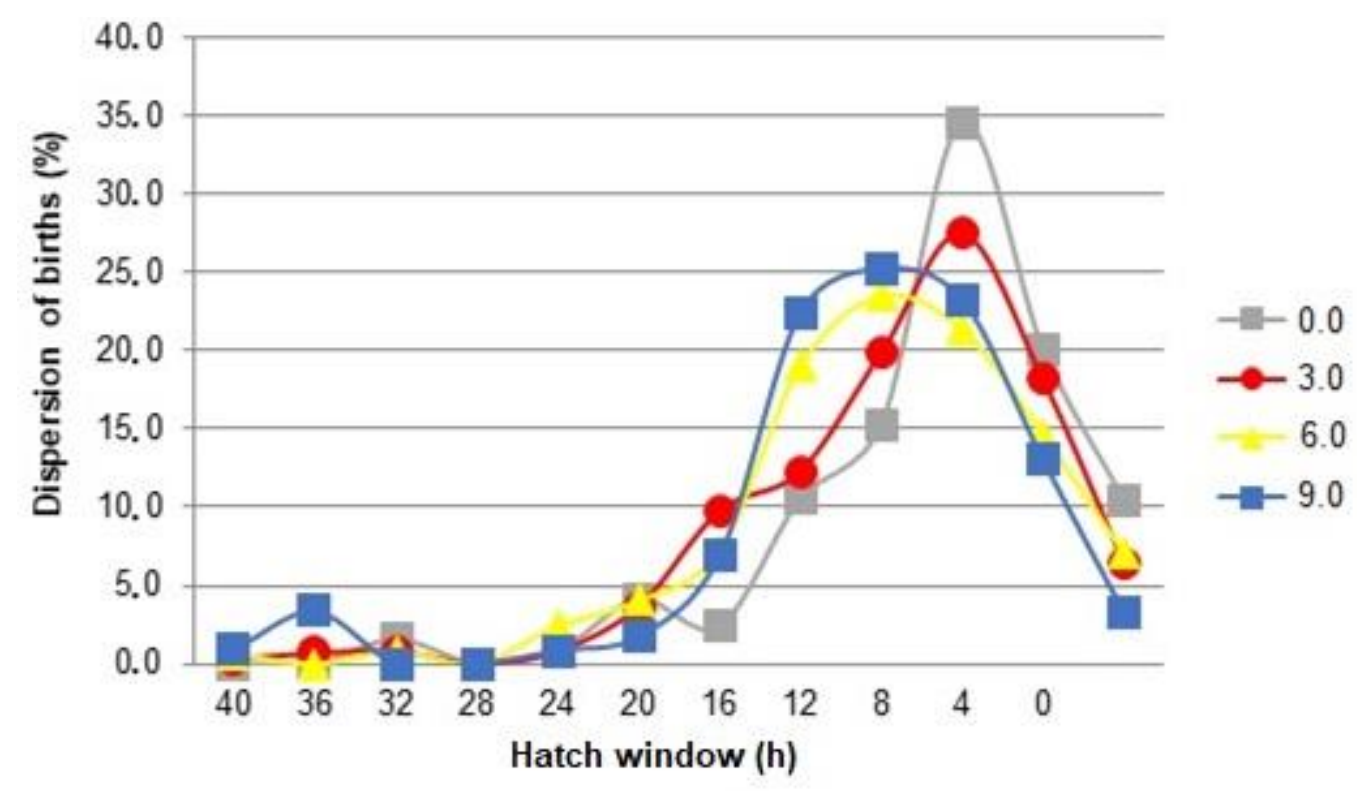

Figure 1 Dispersion of births of Japanese quail on hatch window according the level of guava extract in the diet $(0,3,6$ and $9 \mathrm{~g} / \mathrm{kg})$

The use of the guava extract did not affect embryo mortality, live pecking, dead pecking, and contaminated and inverted eggs (Table 3). However, the percentage of infertile eggs was lower in groups that originated from quail that received 3.0 and $9.0 \mathrm{~g} / \mathrm{kg}$ of guava extract in their diets.

Table 3 Embryonic diagnoses from unhatched eggs produced by Japanese quail fed diets containing different levels of guava extract 


\begin{tabular}{|c|c|c|c|c|c|}
\hline \multirow{2}{*}{ Diagnosis, \% } & \multicolumn{4}{|c|}{ Dietary level of guava extract, $\mathrm{g} / \mathrm{kg}$} & \multirow{2}{*}{$P$-value } \\
\hline & 0.0 & 3.0 & 6.0 & 9.0 & \\
\hline Infertile & $3.81^{a}$ & $2.14^{b}$ & $4.74^{\mathrm{a}}$ & $2.59^{b}$ & 0.0231 \\
\hline Phase 1 & 3.65 & 2.59 & 1.21 & 2.75 & 0.2314 \\
\hline Phase 2 & 0.16 & 1.21 & 0.60 & 1.37 & 0.5681 \\
\hline Phase 3 & 0.60 & 0.00 & 2.43 & 0.00 & 0.4581 \\
\hline Phase 4 & 1.21 & 1.21 & 1.21 & 0.77 & 0.9231 \\
\hline Live pecking & 2.75 & 1.98 & 2.14 & 1.98 & 0.9133 \\
\hline Dead pecking & 0.60 & 0.00 & 0.00 & 0.60 & 0.9812 \\
\hline Contaminated & 0.00 & 0.00 & 0.00 & 0.00 & 1.0000 \\
\hline Inverted & 0.00 & 0.00 & 0.82 & 0.00 & 0.7123 \\
\hline
\end{tabular}

a,b Within each row, means with a common superscript were not different by Fisher's exact test at $P=0.05$

The results of the incubation parameters and the quality of newly hatched quail are shown in Table 4. The use of up to $3.0 \mathrm{~g} / \mathrm{kg}$ of guava extract in the diet increased the weight of both eggs and the newly hatched quail.

Table 4 Embryonic development of newly hatched quail from Japanese quail breeders fed diets containing different levels of guava extract

\begin{tabular}{|c|c|c|c|c|c|c|}
\hline \multirow{2}{*}{ Variable } & \multicolumn{4}{|c|}{ Dietary level of guava extract, g/kg } & \multirow{2}{*}{$P$-value } & \multirow{2}{*}{ SEM } \\
\hline & 0.0 & 3.0 & 6.0 & 9.0 & & \\
\hline Egg weight (g) & $11.78^{\mathrm{ab}}$ & $12.04^{\mathrm{a}}$ & $11.51^{\mathrm{b}}$ & $11.73^{\mathrm{b}}$ & 0.001 & 0.08 \\
\hline Quail chick weight (g) & $7.86^{b}$ & $8.11^{\mathrm{a}}$ & $7.61^{\mathrm{c}}$ & $7.90^{\mathrm{ab}}$ & 0.001 & 0.06 \\
\hline Quail chick length (cm) & 9.87 & 9.90 & 9.89 & 10.02 & 0.132 & 0.05 \\
\hline Weight of yolk sac (g) & 0.51 & 0.61 & 0.52 & 0.52 & 0.155 & 0.04 \\
\hline Net weight of quail chick (g) & $7.53^{\mathrm{ab}}$ & $7.73^{\mathrm{a}}$ & $7.36^{b}$ & $7.64^{\mathrm{ab}}$ & 0.007 & 0.08 \\
\hline Small intestine weight (g) & 0.39 & 0.36 & 0.37 & 0.37 & 0.731 & 0.02 \\
\hline Percentage quail chick on egg & $69.24^{\mathrm{ab}}$ & $69.41^{\mathrm{a}}$ & $67.93^{b}$ & $69.44^{\mathrm{ab}}$ & 0.042 & 0.43 \\
\hline Percentage net weight of quail chick & 64.86 & 64.41 & 63.48 & 65.04 & 0.061 & 0.44 \\
\hline Percentage yolk sac & 6.27 & 7.24 & 6.54 & 6.32 & 0.314 & 0.41 \\
\hline Percentage small intestine & 4.84 & 4.41 & 4.69 & 4.49 & 0.480 & 0.21 \\
\hline
\end{tabular}

a,b Within each row, means with a common superscript were not different by Tukey test at $P=0.05$

No significant difference was observed in the quality score of newly hatched quails that resulted from the level at which guava extract was included in the diet of the parents (Table 5).

Table 5 Quality score (0 to 100 points*) of newly hatched quail from Japanese quails breeders fed diets containing different levels of guava extract 


\begin{tabular}{|c|c|c|c|c|c|}
\hline \multirow{2}{*}{ Score $(\%)$} & \multicolumn{4}{|c|}{ Dietary level of guava extract, $\mathrm{g} / \mathrm{kg}$} & \multirow{2}{*}{$P$-value } \\
\hline & 0.0 & 3.0 & 6.0 & 9.0 & \\
\hline$<70$ & 0.00 & 0.00 & 0.00 & 0.00 & 0.719 \\
\hline $71-75$ & 0.00 & 0.00 & 0.00 & 0.00 & 0.719 \\
\hline $76-80$ & 0.80 & 0.00 & 0.00 & 0.00 & 0.752 \\
\hline $81-85$ & 2.40 & 0.79 & 3.23 & 0.00 & 0.910 \\
\hline $86-90$ & 14.40 & 11.90 & 6.45 & 10.26 & 0.212 \\
\hline $91-95$ & 15.20 & 26.98 & 22.58 & 19.66 & 0.247 \\
\hline $96-100$ & 67.20 & 60.32 & 67.74 & 70.09 & 0.447 \\
\hline
\end{tabular}

${ }^{*}$ Score adapted from Tona et al. (2003)

The use of guava extract improved the intestinal histomorphometry parameters and resulted in greater villus height, crypt depth, and villus to crypt ratio (Table 6).

Table 6 Embryonic development of intestinal mucosal in the duodenum of newly hatched quail chicks from Japanese quail breeders on feeding diets containing different levels of guava extract

\begin{tabular}{|c|c|c|c|c|c|c|}
\hline \multirow{2}{*}{ Variable } & \multicolumn{4}{|c|}{ Dietary level of guava extract, g/kg } & \multirow{2}{*}{$P$-value } & \multirow{2}{*}{ SEM } \\
\hline & 0.0 & 3.0 & 6.0 & 9.0 & & \\
\hline Villus $(\mu \mathrm{m})$ & $224.90^{\mathrm{b}}$ & $241.76^{\mathrm{a}}$ & $243.50^{a}$ & $246.67^{\mathrm{a}}$ & 0.035 & \pm 5.67 \\
\hline Crypt $(\mu \mathrm{m})$ & $173.58^{b}$ & $201.99^{a}$ & $207.70^{\mathrm{a}}$ & $209.74^{a}$ & $<0.001$ & \pm 4.23 \\
\hline Villus: crypt $(\mu \mathrm{m})$ & $1.293^{\mathrm{a}}$ & $1.211^{\mathrm{ab}}$ & $1.189^{b}$ & $1.188^{b}$ & 0.043 & \pm 0.03 \\
\hline
\end{tabular}

a,b Within each row, means with a common superscript were not different by Tukey test at $P=0.05$

The hatchability percentage and the hatch window were not affected by the use of guava extract in the diets. Therefore, these levels of guava extract were not sufficient to alter hatchability. According to Pappas et al. (2006), hatchability and fertility are closely related to the functioning of the antioxidant system of both the breeder and the egg. Thus, the inclusion of an antioxidant component in the breeder's diet could improve the egg hatching rate by minimizing the quality loss of egg components owing to oxidation during embryonic development. Araújo et al. (2018) verified that in ovo injection of vitamin E increases the hatching rate and reduces the hatch window of broiler chickens. Additionally, Contini (2016) evaluated the effect of functional oils in the diets of breeders of different ages on their reproductive performance and their progeny. The results of that study verified that animals that received the functional oils showed higher hatchability and fertility rates. The absence of a stressor agent that requires the action of ellagic acid as an antioxidant could result in a lack of response on these incubation parameters.

Although the hatch window was not affected by the guava extract, it was considered normal for Japanese quail. Babacanoğlu et al. (2018) verified that the hatchability rate of Japanese quail was not affected by in ovo injections of $\alpha$-tocopherol, although the hatch window increased. A small hatch window is positive, as it makes handling easier and promotes the conservation of the quality of newly hatched quail. A large hatch window decreases chick quality, owing to dehydration and thermal stress, and hampers the formation of the gastrointestinal tract as a result of delayed food provision.

Although lower infertility rates were detected in unhatched eggs that originated from animals that received the guava extract, these did not differ from those of the control group. The semen characteristics of quail, especially those related to lipids, can be affected by nutrition. Al-Daraji et al. (2010) concluded that fish oil and flaxseed oil can improve the reproductive performance of male quail by improving the semen characteristics. Biswas et al. (2007) concluded that supplementation of dietary vitamin E improves the semen characteristics in male Japanese quail. Thus, in this study it was expected that the antioxidant substances in 
the guava extract would improve the reproductive rates by enhancing sperm mobility and by protecting sperm against free radicals.

The use of up to $3.0 \mathrm{~g} / \mathrm{kg}^{-1}$ of guava extract in the diet increased the egg weight, quail chick weight, and the villus to crypt ratio. It is possible that the increased villus to crypt ratio resulted in an improvement in nutrient absorption and better performance of neonate quails.

The quail chick length was not affected by the treatments. The length of one-day-old chicks is related to their yolk-free body mass, and serves as an indication of embryonic growth through the transformation of yolk sac nutrients into body mass (Wolanski et al., 2006).

The authors did not verify the differences in the yolk sac percentage of neonate quails. Yolk is a source of nutrients that are necessary for the embryo to grow and hatch and contains proteins, carbohydrates, fats, vitamins, and minerals (Saraswati et al., 2015). Through the process of fatty acid oxidation, lipids become the main energy source during embryonic development and are used for tissue growth (Yadgary et al., 2013).

The quality score of newly hatched quail chicks was similar among the treatments. It was expected that the use of the guava extract as an antioxidant would improve the development of embryos and, consequently, the quality score of neonate quails. Araújo et al. (2018) evaluated the in ovo injection of vitamin $E$ in breeder broiler eggs and observed that the physical quality score in chicks that originated from supplemented eggs was higher. The physical quality of newly hatched chicks is related to the breeder's age. This was corroborated by Araújo et al. (2017) who stated that eggs that originated from older Japanese breeder quail resulted in higher-quality quail. In the present study, the incubated eggs came from Japanese breeder quail of the same age, possibly leading to non-significant differences in the quality score of newborn quail among the treatments.

The intestinal development of birds is influenced by the nutrients from lipids in the yolk sac and the proteins in the albumen (Santos et al., 2010). Similarly, Gomes et al. (2007) stated that better development of the small intestine assists the animal's metabolism to respond to the better nutrient absorption. The relationships among the villus height, crypt depth, and villus to crypt ratio are related directly to the capacity of the small intestine to absorb nutrients (Kuzmuk et al., 2005). This can contribute to better development and productivity in adult animals, as they would have better nutrient absorption conditions owing to the enhanced villi and crypts of the duodenum. It is possible that the antioxidant substances in the guava extract that acted against free radicals were effectively capable of protecting the integrity of villus membranes in the duodenum. Furthermore, they promoted the development of the duodenum, and consequently improved the animals' intestinal health by increasing the absorption area. This would support the statements of Surai et al. (2016) that antioxidants in the egg yolk can control oxidation by reducing or disabling free radicals prior to acting on the chick's organ tissues.

Further studies should be carried out to elucidate the transfer rate of the antioxidant substances from the yolk sac to the progeny and the antioxidant effect of ellagic acid transferred by breeder quail.

\section{Conclusions}

Inclusion of $3.0 \mathrm{~g} / \mathrm{kg}$ of guava residue extract in the feed of Japanese breeder quails increased the weight of quail chicks and resulted in a greater villus to crypt ratio.

\section{Acknowledgements}

The authors thank Fundação de Amparo à Pesquisa do Estado de Goiás (Fapeg) for support of this study.

\section{Authors' Contributions}

HPFX, HHCM and NSML conceived and designed the experiments. HPFX, ICSA, NFO and ALP performed the experiments. ICSA and NSML analysed the data. NSML, AGM and HHCM contributed reagents, materials, and analytical tools. HPFX, HHCM and HFO wrote the paper. HFO edited the manuscript.

\section{Conflict of Interest Declaration}

The authors have no conflict of interest to declare.

\section{References}

Al-Daraji, H.J., Al-Mashadani, H.A., Al-Hayani, W.K., Mirza, H.A. \& Al-Hassani, A.S. (2010). Effect of dietary supplementation with different oils on productive and reproductive performance of quail. Int. J. Poult. Sci. 9(5), 429-435.

Araújo, I.C.S., Café, M.B., Noleto, R.A., Martins, J.M.S., Ulhoa, C.J., Guareschi, G.C., Reis, M.M. \& Leandro, N.S.M., 2019. Effect of vitamin $E$ in ovo feeding to broiler embryos on hatchability, chick quality, oxidative state, and performance. Poult. Sci. 98, 3652-3661. https://doi.org/10.3382/ps/pey439

Araújo, I.C.S., Mesquita, M.A., Andrade, M.A., Castejon, F.V., Café, M.B., Arnhold, E. \& Leandro, N.S.M., 2015. Efeito do período e temperatura de armazenamento de ovos férteis sobre o rendimento de incubação e características 
de qualidade de codornas neonatas. Arq. Bras. Med. Vet. Zootec. 67, 1693-1702. http://dx.doi.org/10.1590/16784162-8012

Araújo, I.C.S., Mesquita, M.A., Café, M.B., Stringhini, J.H., Paz, P.H.S., Noleto, R.A. \& Leandro, N.S.M., 2017. Effect of breeder age and storage conditions of Japanese quail eggs on hatchability, quail neonate quality, and bursa of Fabricius characteristics. R. Bras. Zootec. 46, 731-739. http://dx.doi.org/10.1590/s1806-92902017000900004

Babacanoğlu, E., Karageçili, M.R. \& Karadaş, F., 2018. Effects of egg weight and in ovo injection of a-tocopherol on chick development, hatching performance, and lipid-soluble antioxidant concentrations in quail chick tissues. Arch. Anim. Breed. 61, 179-189. https://doi.org/10.5194/aab-61-179-2018

Biswas, A., Mohan, J., Sastry, K.V. \& Tyagi, J.S., 2007. Effect of dietary vitamin E on the cloacal gland, foam and semen characteristics of male Japanese quail. Theriogenology, 67, $259-263$. https://doi.org/10.1016/j.theriogenology.2006.07.010

Brasil Agência Nacional de Vigilância Sanitária. Formulário de Fitoterápicos da Farmacopeia Brasileira/Agência Nacional de Vigilância Sanitária 2011. Accessed 17 March 2020.

https://portalarquivos2.saude.gov.br/images/pdf/2014/julho/14/Formulario-de-Fitoterapicos-da-FarmacopeiaBrasileira-sem-marca.pdf

Contini, J.P., 2016. Óleos funcionais em dietas de frangos de corte, matrizes e progênie. Msc (Animal Science) thesis, Universidade Federal do Paraná, Brazil.

Genchev, A., 2012. Quality and composition of Japanese quail eggs (Coturnix japonica). Trak. J. Sci. 10, 91-101.

Gomes, J.D.F., Putrino, S.M. \& Martelli, M.R., 2007. Morfologia de órgãos digestivos de suínos de linhagens modernas durante as fases de crescimento, terminação e pós-terminação. Acta Sci. Anim. Sci. 29, 261-266. http://dx.doi.org/10.4025/actascianimsci.v29i3.553

Haida, K.S., Haas, J., Mello, S.A., Haida, K.S., Abrão, R.M. \& Sahd, R., 2015. Compostos fenólicos e atividade antioxidante de goiaba (Psidium guajava L.) fresca e congelada. Rev. Fitos Eletr. 9, 37-44. http://dx.doi.org/10.5935/2446-4775.20150004

Kuzmuk, K.N., Swanson, K.S., Tappenden, K.A., Schook, L.B. \& Fahey Júnior, G.C., 2005. Diet and age affect intestinal morphology and large bowel fermentative end-product concentrations in senior and young adult dogs. J. Nutr. 135, 1940-1945. https://doi.org/10.1093/jn/135.8.1940

Luna, L.G., 1968. Manual of the histologic staining methods of the armed forces institute of pathology. 3rd ed. McGraw Hill, New York.

Pappas, A.C., Acamovic, N.H.C., Sparks, N.H.C., Surai, P.F. \& McDevitt, R.M., 2006. Effects of suplementing broiler breeder diets with organoselenium compounds and polyunsatured fatty acids on hatchability. Poult. Sci. 85, 15841593. https://doi.org/10.1093/ps/85.9.1584

Pappas, A.C., Zoidis, E., Surai, P.F. \& Zervas, G., 2008. Selenoproteins and maternal nutrition. Comp. Biochem. Physiol. Part B Biochem. Mol. Biol. 151, 361-372. https://doi.org/10.1016/j.cbpb.2008.08.009

Priyadarsini, I.K., Khopde, S.M., Kumar, S.S. \& Mohan, H.J., 2002. Free radical studies of ellagic acid, a natural phenolic antioxidant. J Agric Food Chem, 50, 2200-2206. https://doi.org/10.1021/jf011275g

$\mathrm{R}$ Core Team, 2016. A language and environment for statistical computing. Version 3.4.4. R Foundation for Statistical Computing, Vienna, Austria.

Rostagno, H.S., Albino, L.F.T., Donzele, J.L., Gomes, P.C., Oliveira, R.F., Lopes, D.C., Ferreira, A.S., Barreto, S.L.T. \& Euclides, R.F., 2011. Tabelas brasileiras para aves e suínos: composição de alimentos e exigências nutricionais. Editora da Universidade Federal de Viçosa, Minas Gerais, Brazil.

Rutz, F., Anciuti, M.A., Xavier, E.G., Roll, V.F.B. \& Rossi, P., 2007. Avanços na fisiologia e desempenho reprodutivo de aves domésticas. Rev. Bras. Reprod. Anim. 31, 307-317.

Santos, T.T., Corzo, A., Kidd, M.T., McDaniel, C.D., Torres Filho, R.A. \& Araújo, L.F., 2010. Influence of in ovo inoculation with various nutrients and egg size on broiler performance. J. Appl. Poult. Res. 19, 1-12. https://doi.org/10.3382/japr.2009-00038

Saraswati, T.R. \& Tana, S., 2015. Development of Japanese Quail (Coturnix Coturnix Japonica) embryo. Int. J. Sci. Eng. 8, 38-41. https://ejournal.undip.ac.id/index.php/ijse/article/download/7935/pdf

Selim, S.A., Gaafar, K.M. \& El-Ballal, S.S., 2012. Influence of in-ovo administration with vitamin E and ascorbic acid on the performance of Muscovy ducks. Emir. J. Food Agric. 24, 264-271.

Surai, P.F., Fisinin, V.I. \& Karadas, F., 2016. Antioxidant systems in chick embryo development. Part 1. Vitamin E, carotenoids and selenium. Anim. Nutr. 31, 1-11. https://doi.org/10.1016/j.aninu.2016.01.001

Surai, P.F., Karadas, F., Pappas, A.C. \& Spark, N.H.C., 2006. Effect of organic selenium in quail diet on its accumulation in tissues and transfer to the progeny. Br. Poult. Sci. 47, 65-72. https://doi.org/10.1080/00071660500475244

Tona, K., Bamelis, F., Ketelaere, B., Bruggeman, V., Moraes, V.M., Buyse, J., Onagbesan, O. \& Decuypere E., 2003. Effects of egg storage time on spread of hatch, chick quality, and chick juvenile growth. Poult. Sci. 82, 736-741. https://doi.org/10.1093/ps/82.5.736

Wolanski, N.J., Renema, R.A., Robinson, F.E., Carney, V.L. \& Fancher, B.I., 2006. Relationship between chick conformation and quality measures with early growth traits in males of eight selected pure or commercial broiler breeder strains. Poult. Sci. 85, 1490-1497. https://doi.org/10.1093/ps/85.8.1490

Yadgary, L., Kedar, O., Adepeju, O. \& Uni, Z., 2013. Changes in yolk sac membrane absorptive area and fat digestion during chick embryonic development. Poult. Sci. 92, 1634-1640. 